\title{
Fase Nova
}

$P$ ara melhor corresponder à sua finalidade, propóe-se a Revista do Serviço Público a introduzir algumas normas, que julga de grande utilidade, na apresentação dos trabalhos que oferece aos seus leitores, e ainda encetar politica que objetive maiores contactos entre o funcionalismo e mais ampla divulgação das atividades, estrutura e regime de trabalho dos diferentes setores do Departamento Administrativo do Serviço Público, empenhado desde a fundação no esfôrço por bem servir a administração pública brasileira.

Tendo em vista essas iniciativas, não será impertinente afirmar que dará início, assim, a Revista do Serviço Público, a uma nova fase, envidando diligências pelo estudo e conhecimento proveitoso de problemas de interêsse do país.

Procurando acompanhar a evolução dos recursos técnicos de que se têm servido as melhores publicações estrangeiras, passará a adotar, em seus artigos, o sistema da Classificação Decimal Universal (C.D.U.), estabelecedor das novas normas de qualificação bibliográfica, cujas vantagens têm sido objeto de aceitação universal, não só por parte dos especialistas, como do público ledor.

No intuito de retraçar a ação desenvolvida pelo D.A.S.P., nos seus diversos aspectos, apresentará a Revista cada uma dos setores Jêste Departamento, com tôdas as informações que possam concorrer para completo conhecimento das suas múltiplas atividades e realizações. 
Desta forma, tomando os melhores frutos de experiência dos antecessores, crê a atual Direção contribuir de modo positivo para que mais avisadamente se preencham as finalidades desta publicação, vanguardeira na luta pela cultura administrativa brasileira.

Desnecessário finalmente dizer que as páginas da Revista estão abertas a todos os funcionários públicos e a todos os estudiosos, sem exigência outra que não a da serenidade dos trabalhos destinados a impressão. 